\title{
Neurons Lacking Huntingtin Differentially Colonize Brain and Survive in Chimeric Mice
}

\author{
Anton Reiner, ${ }^{1}$ Nobel Del Mar, ${ }^{1}$ Christopher A. Meade, ${ }^{1}$ Huaitao Yang, ${ }^{1}$ loannis Dragatsis, ${ }^{2}$ Scott Zeitlin, ${ }^{3}$ and \\ Daniel Goldowitz ${ }^{1}$ \\ 1 Department of Anatomy and Neurobiology, College of Medicine, The University of Tennessee, The Health Science \\ Center, Memphis, Tennessee 38163, and Departments of ${ }^{2}$ Genetics and Development and ${ }^{3}$ Pathology, Columbia \\ University, New York, New York 10032
}

To determine whether neurons lacking huntingtin can participate in development and survive in postnatal brain, we used two approaches in an effort to create mice consisting of wildtype cells and cells without huntingtin. In one approach, chimeras were created by aggregating the 4-8 cell embryos from matings of $\mathrm{Hdh}{ }^{+/-}$mice with wild-type 4-8 cell embryos. No chimeric offspring that possessed homozygous $\mathrm{Hdh}^{-1-}$ cells were obtained thereby, although statistical considerations suggest that such chimeras should have been created. By contrast, $\mathrm{Hdh}^{-1-}$ ES cells injected into blastocysts yielded offspring that were born and in adulthood were found to have $\mathrm{Hdh}{ }^{-1-}$ neurons throughout brain. The $\mathrm{Hdh}^{-1-}$ cells were, however, 5-10 times more common in hypothalamus, midbrain, and hindbrain than in telencephalon and thalamus. Chimeric animals tended to be smaller than wild-type littermates, and chimeric mice rich in $\mathrm{Hdh}^{-1-}$ cells tended to show motor abnor- malities. Nonetheless, no brain malformations or pathologies were evident.

The apparent failure of aggregation chimeras possessing $\mathrm{Hdh}^{-1-}$ cells to survive to birth is likely attributable to the previously demonstrated critical role of huntingtin in extraembryonic membranes. That $\mathrm{Hdh}{ }^{-1-}$ cells in chimeric mice created by blastocyst injection are under-represented in adult telencephalon and thalamus implies a role for huntingtin in the development of these regions, whereas the neurological dysfunction in brains enriched in $\mathrm{Hdh}{ }^{-/-}$cells suggests a role for huntingtin in adult brain. Nonetheless, the lengthy survival of $\mathrm{Hdh}^{-1-}$ cells in adult chimeric mice indicates that individual neurons in many brain regions do not require huntingtin to participate in normal brain development and to survive.

Key words: basal ganglia; cortex; development; Huntington's disease; HD gene; colonization
Huntington's disease (HD) is a dominant hereditary neurodegenerative disorder characterized by progressive cognitive decline and motor dysfunction (Bruyn and Went, 1986; Wilson et al., 1987; Albin and Tagle, 1995). The major site of neuron loss in $\mathrm{HD}$ is the striatal part of the basal ganglia, and it is this loss that accounts for the progressive movement disorder (Vonsattel et al., 1985; De La Monte et al., 1988; Hedreen et al., 1991; Storey et al., 1992). The gene and the specific mutation responsible for HD have been known for several years (Huntington's Disease Collaborative Research Group, 1993). The gene product, huntingtin, is of unknown function, although several lines of evidence suggest that it is involved in vesicular trafficking (DiFiglia et al., 1995; Sharp et al., 1995; Wood et al., 1996). The mutation in the HD gene involves an expansion of a CAG repeat at the $5^{\prime}$ end of the gene beyond its normal 10-35 repeat range (Albin and Tagle, 1995). The means by which this mutation causes preferential destruction of the striatum is uncertain. Several lines of evidence

\footnotetext{
Received May 24, 2001; revised July 20, 2001; accepted July 23, 2001.

This research was supported by a Cure Huntington's Disease Contract from the Hereditary Disease Foundation (to D.G. and A.R.), grants from the Hereditary Disease Foundation and the Wills Foundation (to S.Z.), and National Institute of Health Grants NS19620 and NS28721 (to A.R.). We thank Lydia Hu and Richard Cushing for their excellent technical assistance and are grateful to Dr. Jonathan Coffman for his assistance with some of the genotyping.

Correspondence should be addressed to Dr. Anton Reiner, Department of Anatomy and Neurobiology, The University of Tennessee, The Health Science Center, 855 Monroe Avenue, Memphis, TN 38163. E-mail: areiner@utmem.edu.

S. Zeitlin's present address: Department of Neuroscience, University of Virginia School of Medicine, P.O. Box 801392, Charlottesville, VA 22908-1392.

Copyright (C) 2001 Society for Neuroscience $\quad 0270-6474 / 01 / 217608-12 \$ 15.00 / 0$
}

suggest that, whatever its precise mechanism of action, the HD mutation acts in a "gain-of-function" manner. First, HD shows autosomal dominant inheritance. Second, in a single fortuitously discovered case, one copy of the gene coding for huntingtin was found to be inactivated by a translocation, yet this individual did not have HD symptoms despite having only $50 \%$ of normal HD gene expression (Ambrose et al., 1994; Persichetti et al., 1996). Third, homozygous knock-out of the gene coding for huntingtin in mice $(H d h)$ is embryonically lethal (Duyao et al., 1995; Nasir et al., 1995; Zeitlin et al., 1995), whereas homozygous mutation of the HD gene in humans is not (Wexler et al., 1987; Myers et al., 1989; Gusella and MacDonald, 1996). Finally, humans homozygous for the HD mutation show no clear differences from heterozygotes in disease onset or progression (Wexler et al., 1987; Myers et al., 1989; Gusella and MacDonald, 1996).

The possibility remains, however, that the HD mutation does, at least in part, act as a loss-of-function mutation, and this effect for some unknown reason is not manifest until well after birth. For example, it could be the case that the mutated version of huntingtin in HD heterozygotes comes to neutralize the function of the normal protein because of unknown age-related changes in the behavior of either the mutant or normal protein (Cattaneo et al., 2001). If in fact this type of event occurs and contributes to HD pathogenesis, one would expect that neurons lacking huntingtin should survive poorly in mice engineered to possess an $H d h$ deletion. To examine this possibility, we overcame the fact that homozygous deletion of $H d h$ is embryonically lethal by a chimeric strategy (Goldowitz et al., 1992; Duyao et al., 1995; 
Nasir et al., 1995; Zeitlin et al., 1995; Dragatsis et al., 1998). Our results show that neurons devoid of huntingtin can participate in normal brain formation and survive in adult mouse brain. Nonetheless, huntingtin does appear to play some role in neural functioning, because motor impairment was evident in many chimeric mice for which the brains were enriched in $\mathrm{Hdh}{ }^{-/-}$neurons. Additionally, huntingtin appears to be required for proliferation or survival of neurons in some brain regions during early development, because we observed that $H d h^{-/-}$cells preferentially colonize hypothalamus, midbrain, and hindbrain and are scarce in telencephalon and thalamus.

\section{MATERIALS AND METHODS}

Subjects. Hdh ${ }^{+/-}$mice (Duyao et al., 1995) and ROSA26 mice were obtained from the Jackson Laboratories (Bar Harbor, ME) and bred in our colony at the University of Tennessee. The Hdh disruption in the Duyao et al. (1995) mice involves a deletion of exons 4 and 5, resulting in the abolition of expression for $H d h$. These mice were used together with the ROSA26 mice to create chimeras by the method of early embryo aggregation (with the embryos from both lines being at the 4-8 cell stage at the time of aggregation), as described below. $H d h^{-1-} \leftrightarrow H d h^{+/+}$ chimeric mice also were created in the laboratory of Dr. Scott Zeitlin by injecting embryonic stem (ES) cells nullizygous for $H d h$ into wild-type blastocysts (Dragatsis et al., 1998). The Hdh nullizygous ES cells possessed a homozygous-targeted disruption of both Hdh alleles (Dragatsis et al., 1998). The Hdh disruption in this case involved deletion of the promoter, exon 1 , and flanking intronic sequences $\left(H d h^{t m 1 S z i}\right)$, again resulting in the loss of $H d h$ expression (Zeitlin et al., 1995). So that their detection could be facilitated in chimeric tissues, the $H d h^{-1-}$ ES cells also bore a lac $Z$ transgene that had been introduced into their genome by the mating strategy described below. All studies were conducted in accordance with National Institutes of Health and Society for Neuroscience policies on the ethical use of animals in research.

Production of aggregation chimeras. Aggregation chimeras were created by standard methods (Goldowitz et al., 1992), with the goal of creating mice that consisted of a mixture of $H d h^{-1-}$ cells and wild-type cells. Briefly, $H d h^{+/-}$females were superovulated and mated with $H d h^{+/-}$ males. Plug-positive females were taken $2 \mathrm{~d}$ later, and their oviducts were flushed with medium to harvest the $4-8$ cell stage embryos. The wildtype component of the chimera was derived from the 4-8 cell stage embryos of the ROSA26 strain of mice, which allows for identification of cells from the wild-type contribution to the chimeras by an X-gal histochemical procedure for the lac $Z$ transgene product (Friedrich and Soriano, 1991). Note that, in chimeras created by the method of aggregating two 4-8 cell stage embryos, the $H d h^{-1-}$ cells would be able equally, in principle, to colonize all parts of the embryo, including the extraembryonic membranes (Le Dourain and McLaren, 1984).

Production of chimeras by blastocyst injection. Hdh ${ }^{-1-} /$ ROSA26 ES cells were obtained by dissociating and culturing the inner cell mass from embryonic day 3.5 (E3.5) embryos that were the products of a mating strategy designed to produce embryos that possessed a homozygous $H d h$ deletion and also possessed the ROSA26 transgene. In the first step of this mating strategy $H d h^{+/-}$female mice were mated with males homozygous for the ROSA26 lacZ transgene. In the second step of the mating strategy the $H d h^{+/-} / R O S A 26$ offspring were intercrossed, and E3.5 blastocysts were obtained from this mating, $75 \%$ of which bore the ROSA26 transgene. ES cell lines were derived from these blastocysts, and Southern and Western analyses were performed to identify those ES cell lines that were $H d h^{-1-} . H d h^{-1-} / R_{O S A} 6 \mathrm{ES}$ cells were injected into wild-type C57BL/6 (B6) host E3.5 blastocysts via standard procedures, and the injected blastocysts were transferred into the uterine horns of pseudopregnant females. Any of three different lines of $H d h^{-/-}$ES cells described previously (A, B, or I) were used for these injections (Dragatsis et al., 1998). These procedures have been described in detail previously (Dragatsis et al., 1998). After birth, the chimeric mice were monitored and killed at various time points up to $\sim 1$ year of age. Note that, because ES cells preferentially colonize the embryonic ectoderm and poorly colonize extraembryonic tissues derived from the inner cell mass and completely fail to colonize extraembryonic tissues derived from trophectoderm, in the chimeras made by blastocyst injection the $H d h^{-1-}$ cells are completely absent from trophectoderm derivatives and are mainly absent from the extraembryonic membrane derived from inner cell mass tissue (Beddington and Robertson, 1989).
PCR genotyping of $\mathrm{Hdh}^{+/-}$mice used to generate embryos for aggregation chimeras. PCR genotyping was performed as described previously to identify $H d h^{+/-}$mice for breeding purposes (Duyao et al., 1995; Chen et al., 1997; Fusco et al., 1999). Genomic DNA extracted from tail biopsies was used to detect mice bearing an $H d h$ knock-out allele in their genome by PCR genotyping mice for $H d h$ and for the neomycin resistance selection cassette (neo) introduced during the creation of the $H d h$ deletion. The primers for the detection of huntingtin DNA in these PCR assays were $5^{\prime}$-CAAATGTTGCTTGTCTGGTG-3' and 5'-GTCAGTCGAGTGCACAGTTT-3'. The amplified Hdh DNA fragment has a size of $150 \mathrm{bp}$. The primers for the detection of neo DNA were $5^{\prime}$ CTTGGGTGGAGAGGCTATTC-3' and 5'-AGGTGAGATGACAGGAGATC-3'. The amplified neo PCR product has a size of $280 \mathrm{bp}$. One-half of a microliter of DNA template $(250 \mathrm{ng} / \mu \mathrm{l}$ genomic DNA) was used, and the PCR for $H d h$ and neo for each animal was run simultaneously in the same thin-walled PCR tube. The PCR reaction solution contained the following: $2.0 \mu \mathrm{l}$ of $10 \times$ PCR buffer $(10 \mathrm{~mm}$ Tris- $\mathrm{HCl}, \mathrm{pH}$ $9.0,50 \mathrm{~mm} \mathrm{KCl}, 0.1 \%$ Triton X-100), $1.6 \mu \mathrm{l}$ of $25 \mathrm{mM} \mathrm{MgCl}_{2}, 0.4 \mu \mathrm{l}$ of 10 mM dNTPs, $2.0 \mu \mathrm{l}$ of $10 \mu \mathrm{M}$ amounts of the four primers, $2.76 \mu \mathrm{l}$ of DNA tracking dye, $4.66 \mu \mathrm{l}$ of $\mathrm{dH}_{2} \mathrm{O}$, and $0.08 \mu \mathrm{l}$ of Taq polymerase. Contamination from extraneous DNA was checked by replacing the cellular template with water. Amplification was performed on a thermal cycler (MJ Research, Watertown, MA), typically under the following cycle conditions: denaturation at $94^{\circ} \mathrm{C}$ for $30 \mathrm{sec}$, annealing at $55^{\circ} \mathrm{C}$ for $45 \mathrm{sec}$, and extension at $72^{\circ} \mathrm{C}$ for $1 \mathrm{~min}$ for a total 30 cycles. After PCR amplification, aliquots of reaction product were analyzed by electrophoresis on ethidium bromide-impregnated $3 \%$ agarose gels.

PCR genotyping of aggregation chimeras to detect $\mathrm{Hdh}{ }^{-1-}$ cells. So that cells that are homozygous for the $H d h$ knock-out could be detected, it is necessary to detect the presence of neo and find no evidence for the presence of $H d h$. For distinguishing aggregation chimeras bearing homozygous $H d h$ knock-out cells from those bearing a hemizygous $H d h$ deletion, PCR genotyping by tail biopsy is inadequate, because both $H d h^{+/-}$and $H d h^{-1-}$ cells possess neo, and the possible presence of $H d h$ in wild-type cells in the tail biopsy would hide evidence of any $H d h$ cells potentially contributing to the formation of the chimera. Thus to detect the presence of $H d h^{-/-}$cells in the aggregation chimeras, we excised pure populations of ROSA26-negative cells (which come from the $H d h$ knock-out line) from the fixed livers of aggregation chimeras postmortem. Liver slices $(50 \mu \mathrm{m}$ thick) from the aggregation chimeras that had shown a tail-snip PCR signal for neo were prepared and reacted with $\mathrm{X}$-gal as described below. The liver slices were mounted on slides and examined with a dissecting microscope. Patches of cells that were devoid of X-gal labeling and were therefore from the $H d h$ knock-out strain were removed from the tissue with a glass micropipette. These cells were lysed with Proteinase K, and 1-2 $\mu \mathrm{l}$ of the digested material was assayed by PCR to determine whether it was negative for $H d h$. Three primers were used that allowed us to detect differentially the normal $H d h$ gene and the truncated form of the allele created by the targeted disruption of $H d h:$ (1) 5'-ACGTGAGCTGTCCAGGTGAGCC-3'; (2) 5'-TATAGAGTTCTAACTGTAGCCTTG-3'; and (3) 5'-TCGCCGCTCCCGATTCGCAGCATCG-3'. The first and second of these primers amplify a $350 \mathrm{bp}$ fragment of wild-type $H d h$ containing intron 3 and exon 4, whereas the first and third primers amplify a $650 \mathrm{bp}$ fragment of disrupted Hdh containing intron 3 and the neo insert. The PCR reaction solution contained the following: $2 \mu \mathrm{l}$ of $10 \times$ PCR buffer, $1.2 \mu \mathrm{l}$ of $25 \mathrm{mM} \mathrm{MgCl}_{2}$, $0.2 \mu \mathrm{l}$ of $20 \mathrm{~mm}$ dNTPs, $1 \mu \mathrm{l}$ of $20 \mu \mathrm{M}$ amounts of the three primers, 2.76 $\mu \mathrm{l}$ of DNA tracking dye, $10.7 \mu \mathrm{l}$ of $\mathrm{dH}_{2} \mathrm{O}$, and $0.1 \mu \mathrm{l}$ of $7.5 \mathrm{U}$ Taq polymerase. Contamination from extraneous DNA was checked by replacing the cellular template with water. Amplification was performed on a thermal cycler (MJ Research), as described above, and aliquots of reaction product were analyzed by electrophoresis on ethidium bromideimpregnated $3 \%$ agarose gels. To ensure that chimeric mice genotyped as $H d h^{+/+}$by tail biopsy were in fact $H d h^{+/+}$, we performed genotyping of non-ROSA26 liver cells from these animals as well.

Behavioral assessment of chimeras produced by blastocyst injection. Several simple motor/behavioral tests were performed on the chimeras produced by blastocyst injection of $H d h^{-/-} / R O S A 26$ ES cells (Dragatsis et al., 1998). These included a limb-clasping assessment, a wire rod hanging test, an evaluation of the ability to cling to a wire cage being rotated 180 degrees, and a gait analysis. These tests have been shown to be sensitive to the neurological/motor abnormalities seen in mutant mouse models of neurological disease (Mangiarini et al., 1996; Dragatsis et al., 2000). Mice typically were tested once a month. For limb clasping, chimeric mice and nonchimeric littermates were suspended $30 \mathrm{~cm}$ above 
an open cage and over a 1 min period were lowered toward the bottom of the cage. Mice that clasped their limbs within $5 \mathrm{sec}$ of suspension and maintained the clasping during the entire descent were scored as showing a positive limb-clasping response. For the wire rod hanging test, mice were allowed to grasp a narrow wire rod (diameter, $<0.25 \mathrm{~cm}$ ) suspended $30 \mathrm{~cm}$ above a padded work surface and were observed for $1 \mathrm{~min}$. Normal mice can maintain a grip with their forelimbs for the full test duration, so mice that fell within $30 \mathrm{sec}$ of the onset of the test thus were scored as positive for neurological impairment. For the wire cage rotation test, mice were placed on top of a wire cage held $\sim 30 \mathrm{~cm}$ above a padded work surface. Then the cage was rotated $180^{\circ}$ over a period of $1 \mathrm{~min}$ and held for an additional $30 \mathrm{sec}$ in the inverted position. Mice scoring positive for neurological impairment in this test were unable to climb to a position at the top of the rotating frame as it was turned and fell to the work surface (Crawley, 1999). For gait analysis, the hindpaws of mice were dipped in nontoxic fingerpaint and placed on a strip of paper between two guide walls. In the comparisons of chimeras and controls, the distance between successive paw prints and the width between each pair of prints were measured. Body weight was measured in the chimeric mice and a set of 10 age-matched $\mathrm{C} 57 \mathrm{BL} / 6$ males and 10 age-matched C57BL/6 females at $1,3,6$, and 9 months.

Tissue fixation. Under deep Avertin anesthesia, mice used for histological analysis were perfused transcardially with PBS $(0.1 \mathrm{M}$ sodium phosphate buffer, pH 7.4, with $0.9 \% \mathrm{NaCl}$ ), followed by $4 \%$ paraformaldehyde in $0.1 \mathrm{M}$ PB. These mice included all chimeric mice created by the aggregation method, six ES blastocyst injection chimeras and their two B6 controls, and five nonchimeric $\operatorname{ROSA26}$ mice used as controls to demonstrate the ability of the lac $Z$ gene to be expressed ubiquitously throughout the nervous system in mice (Friedrich and Soriano, 1991). The brain and liver were removed and stored in a $20 \%$ sucrose $/ 10 \%$ glycerol solution at $4^{\circ} \mathrm{C}$. Livers from aggregation-chimera mice created by using $R O S A 26$ as the wild-type strain were sectioned with a vibratome at $50 \mu \mathrm{m}$ and used in genotyping, as noted above. The brains of the six ES blastocyst injection chimeras, their two B6 controls, and the control ROSA26 mice were sectioned frozen on a sliding microtome in the transverse plane at $35 \mu \mathrm{m}$. Each of these brains was collected as $6-12$ separate series in $0.1 \mathrm{M} \mathrm{PB}$ and $0.02 \%$ sodium azide and stored until processed for histochemistry, histology, or immunohistochemistry. For four additional ES blastocyst injection chimeras the brains were removed and immersion fixed overnight in $0.2 \%$ paraformaldehyde in $0.1 \mathrm{M}$ PIPES, pH 6.9, plus $2 \mathrm{~mm} \mathrm{MgCl}_{2}$ and $5 \mathrm{~mm}$ EGTA, washed in PBS and $\mathrm{MgCl}_{2}$, cryo-preserved in $30 \%$ sucrose plus $\mathrm{MgCl}_{2}$, embedded in TissueTek OCT compound (Fisher Scientific, Pittsburgh, PA), and frozen. These brains were sectioned in the sagittal plane with a cryostat and mounted on Superfrost Plus glass slides. A series of brain sections for each chimeric mouse created by the blastocyst injection method (and the B6 controls) was stained with cresyl violet or neutral red to study normal brain histology. Additional series were processed by using fluoro-jade labeling to detect any degenerating cells (Schmued et al., 1997). As positive controls in the fluoro-jade studies, C57BL/6 mice were injected intraperitoneally with $1 \mathrm{mg}$ of kainic acid per $30 \mathrm{gm}$ of body weight. This dose was chosen because it gives stage 3 seizures and consistent hippocampal cell death (Schauwecker and Steward, 1997). These animals were perfusion fixed by using the same fixative as for the chimeric mice. Brains were cryosectioned, mounted on glass slides, and processed in parallel with the chimeric tissue for the fluoro-jade demonstration of degenerating neurons.

Demonstration of cell genotype via $\beta$-galactosidase histochemistry. One series of sections through the brain and/or liver of chimeric mice, the B6 control mice, and the nonchimeric ROSA26 control mice was processed for the $\beta$-galactosidase marker by using the procedure of Oberdick et al. (1994), in which sections are incubated at $30-35^{\circ} \mathrm{C}$ overnight in buffer (containing $5 \mathrm{~mm}$ of potassium ferricyanide and ferrocyanide, $2 \mathrm{~mm}$ magnesium chloride, $0.02 \%$ Nonidet P-40, and $0.01 \%$ sodium deoxycholate) with $0.1 \% \mathrm{X}$-gal substrate in dimethyl sulfoxide (Boehringer Mannheim, Indianapolis, IN). Slides were rinsed and counterstained with neutral red to identify and quantify labeled and unlabeled cells. Tissue was dehydrated and cleared in xylenes; coverslips were applied with Permount. This approach identified the cells from the wild-type strain in aggregation chimeras in which the ROSA26 line was used as the wild-type strain and knock-out cells themselves in the blastocyst injection chimeras (because $H d h^{-/-}$cells bore a lac $Z$ transgene expressing $\beta$-galactosidase attributable to the mating strategy described above).

Immunohistochemistry. Immunohistochemical labeling was performed to confirm the absence of huntingtin in X-gal-labeled perikarya in the chimeras created by blastocyst injection and to characterize the effects of the homozygous $H d h$ deletion on these cells by assaying for perturbation in neuropeptide and neurotransmitter expression as well as for the expression of markers of regional or cellular stress. Conventional immunofluorescence or the peroxidase-anti-peroxidase (PAP) procedures were used (Anderson and Reiner, 1990, 1991; Figueredo-Cardenas et al., 1994). Tyramide signal amplification was used to enhance labeling for huntingtin (Fusco et al., 1999). In some cases the immunolabeling also was enhanced by pretreating the free-floating sections with a $30 \mathrm{~min}$ immersion in $10 \mathrm{~mm}$ sodium citrate buffer, $\mathrm{pH} \mathrm{9.0,} \mathrm{at} 85^{\circ} \mathrm{C}$ (Jiao et al., 1999). To detect huntingtin, we used a mouse monoclonal antibody (Mab2170, Chemicon, Temecula, CA). The antibody was generated against amino acids1247-1646 of human huntingtin; its specificity for huntingtin in rodents and humans has been demonstrated previously (Bessert et al., 1995; Trottier et al., 1995; Fusco et al., 1999). Antigens that were screened to assess the normalcy of the blastocyst injection chimera brains possessing $H d h^{-1-}$ cells included vasoactive intestinal polypeptide (VIP), tyrosine hydroxylase (TH), calbindin (CALB), parvalbumin (PARV), glial fibrillary acidic protein (GFAP), substance P (SP), methionine-enkephalin (ENK), neuropeptide Y (NPY), choline acetyltransferase (ChAT), and vasopressin (VP) (Loren et al., 1979; Kiyama et al., 1990; Reiner and Anderson, 1990; Armstrong et al., 1994; Figueredo-Cardenas et al., 1994, 1998; Kawaguchi et al., 1995; Karle et al., 1996; Elmquist et al., 1999). The specificity and sources of the antisera that were used have been described in previous studies (Reiner, 1991; Armstrong et al., 1994; Figueredo-Cardenas et al., 1994, 1998; Karle et al., 1996).

\section{RESULTS}

\section{Aggregation chimeras}

From our efforts to create aggregation chimeras containing cells with a homozygous deletion of the huntingtin gene, 21 chimeric animals were born. Note that we would expect only $25 \%$ of our aggregation chimeras to possess $H d h^{-/-}$cells, because only $25 \%$ of the embryos from our mating of $\mathrm{Hdh}{ }^{+/-}$ females with $H d h^{+/-}$males would be expected to be $H d h^{-1-}$. To distinguish chimeras bearing $H d h^{-/-}$cells from those bearing $H d h^{+/-}$cells, we believed that PCR genotyping of DNA isolated from a tail biopsy would be inadequate, because wild-type cells in the tail biopsy would hide evidence of homozygous Hdh knock-out cells. Thus we used the strategy described in Materials and Methods whereby we excised pure populations of cells from the knock-out line from the fixed liver of postmortem chimeric mice. Of our 21 chimeric animals created by aggregation methods, 12 showed a positive signal for the neo cassette by PCR. The remaining mice (9) were chimeric assemblages of $\mathrm{Hdh}{ }^{+/+}$cells from the knock-out strain and the wild-type strain. Of the 12 showing a positive signal for the neo cassette (indicating at least one $H d h$ null allele), none contained cells that were nullizygous for $H d h$, and all neo-positive cells thus appeared to be $H d h^{+/-}$. The failure of aggregation chimeras with homozygous $H d h$ knock-out cells to be born is extremely unlikely to have occurred by chance, because of the 21 chimeric mice that were phenotyped, approximately five would have been expected to possess $H d h^{-1-}$ cells ( $p<0.05$, by $\chi^{2}$ analysis). Based on these considerations, it seems that the chimeric mice possessing $\mathrm{Hdh}{ }^{-1-}$ cells presumably created by the aggregation method must not have come to term. It is of note that, of the 21 chimeric mice created by aggregation methods that were born, the percentage of contribution from the embryos derived from the $H d h^{+/-}$cross ranged from 5 to $95 \%$. If the same percentage of chimerism can be assumed for the homozygous $H d h$ knock-out chimeras, who are presumed to have died in utero, it would suggest that even a very small percentage of $\mathrm{Hdh}^{-1-}$ cells is incompatible with development to term. 


\begin{tabular}{|c|c|c|c|c|c|c|}
\hline Animal & Clone & Gender $^{a}$ & 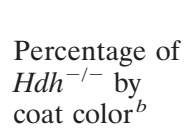 & Age at death ${ }^{c}$ & $\begin{array}{l}\text { Percentage of } \\
\text { wild-type } \\
\text { weight at } 6 \\
\text { months }^{d}\end{array}$ & Motor abnormalities \\
\hline ES4 & A & M & 20 & 13 months & 95 & None \\
\hline ES19 & A & $\mathrm{F}$ & 20 & 13 months & 103 & None \\
\hline ES15 & I & $\mathrm{F}$ & 25 & 12 months & 100 & None \\
\hline ES5 & B & $\mathrm{F}$ & 30 & 12 months & 102 & None \\
\hline ES7 & $\mathrm{B}$ & $\mathrm{F}$ & 30 & 13 months & 92 & None \\
\hline ES8 & I & $\mathrm{F}$ & 30 & 13 months & 90 & None \\
\hline ES16 & A & M & 30 & 12 months & 94 & None \\
\hline ES18 & A & $\mathrm{F}$ & 30 & 11 months & 95 & None \\
\hline ES20 & A & M & 30 & 12 months & 92 & None \\
\hline ES12 & $\mathrm{I}$ & M & 30 & 8 months & 70 & Severe by 20 weeks $^{e}$ \\
\hline ES14 & A & M & 35 & 11 months & 93 & None \\
\hline ES3 & I & $\mathrm{F}$ & 40 & 13 months & 89 & None \\
\hline ES17 & B & $\mathrm{F}$ & 40 & 12 months & 91 & None \\
\hline ES6 & A & M & 40 & 13 months & 86 & Slight clasping ${ }^{f}$ \\
\hline ES11 & A & M & 45 & 9 months & 71 & Severe by 20 weeks $^{e}$ \\
\hline ES9 & $\mathrm{I}$ & $\mathrm{F}$ & 50 & 13 months & 85 & None \\
\hline ES13 & A & M & 50 & 9 months & 70 & Severe by 4 weeks $^{g}$ \\
\hline ES1 & I & $\mathrm{F}$ & 60 & 13 months & 82 & Slight clasping $^{f}$ \\
\hline ES10 & $\mathrm{B}$ & $\mathrm{F}$ & 60 & 6 months & 65 & Severe by 4 weeks ${ }^{g}$ \\
\hline $\mathrm{ES} 23$ & I & M & 60 & 9 months & 73 & Severe by 20 weeks $^{e}$ \\
\hline $\mathrm{ES} 2$ & $\mathrm{I}$ & $\mathrm{F}$ & 65 & 13 months & 80 & Slight clasping $^{f}$ \\
\hline ES22 & A & M & 65 & 8 months & 63 & Severe by 4 weeks $^{g}$ \\
\hline ES21 & B & $\mathrm{F}$ & 75 & 7 months & 60 & Severe by 4 weeks ${ }^{g}$ \\
\hline \multicolumn{7}{|c|}{$\begin{array}{l}{ }^{a} \text { Gender in the chimeras was influenced not only by the gender of the ES cell clone used but also by the gender of the host } \\
\text { embryo and the degree of colonization by cells of either genotype of gender-determining body tissues. }\end{array}$} \\
\hline \multicolumn{7}{|c|}{$\begin{array}{l}{ }^{b} \text { The mice are ordered by increasing ES cell line contribution to coat color to facilitate assessment of the association of } \\
\mathrm{Hdh}^{-/-} \text {ES composition with body weight and behavioral abnormality. }\end{array}$} \\
\hline \multicolumn{7}{|c|}{$\begin{array}{l}{ }^{c} \text { Chimeric mice that displayed no symptoms were killed at } \sim 1 \text { year of age, whereas chimeric mice with behavioral symptoms } \\
\text { were killed at the time they showed severe morbidity. }\end{array}$} \\
\hline \multicolumn{7}{|c|}{$\begin{array}{l}{ }^{d} \text { A sample of } 10 \text { male and } 10 \text { female } \mathrm{C} 57 \mathrm{BL} / 6 \text { mice was used as the age-matched and gender-matched wild-type control } \\
\text { population. Adult body weight was stable in all animals before the onset of morbidity in those showing the severe } \\
\text { abnormalities. Thus, } 6 \text { month body weight is shown for all animals, and none was showing morbidity at the time of } \\
\text { measurement. }\end{array}$} \\
\hline \multicolumn{7}{|c|}{$\begin{array}{l}{ }^{e} \text { Severe deficits on clasping and rod grasping tests at } 4 \text { weeks and severe deficit on cage rotation test at } 20 \text { weeks. } \\
{ }^{f} \text { Mild clasping was observed at } 20 \text { weeks, but no deficit was seen in the other tests at any time. }\end{array}$} \\
\hline${ }^{f}$ Mild clas & ng was ob & erved at 20 & eeks, but no deficit & vas seen in the otl & tests at any time. & \\
\hline
\end{tabular}

\section{Blastocyst injection chimeras: Characteristics of Hdh $^{-/-}$chimeras}

By contrast, blastocyst injection of $H d h^{-1-}$ ES cells yielded viable chimeric mice (10 males, 13 females) that were able to live well into adulthood (Table 1). Chimeras were generated with any of three $H d h$ nullizygous ES cell lines (two female lines, clones I and $\mathrm{B}$, and one male line, clone A). Southern blot data from organs of some killed chimeras suggested that the coat color chimerism tended to reflect overall bodily chimerism at the DNA level (the ES cell lines were derived from the $129 \mathrm{~Sv} / \mathrm{Ev}$ background and gave rise to agouti animals, whereas the host blastocysts were obtained from C57BL/6 females with black fur). The chimeras were estimated to range from 20 to $75 \%$ in their contribution from the $H d h^{-1-}$ ES-derived mouse strain by their coat color. The body weight of these chimeras ranged from 60 to $100 \%$ of wild-type mice, and body weight was significantly inversely correlated $(r=0.81)$, with the percentage of ES cell-derived contribution indicated by coat color (i.e., the more $H d h^{-/-}$cells, the lower the body weight of the chimera). The male chimeras never mated successfully; there were no pregnancies, and no vaginal plugs were detected in wild-type females housed with male chimeras. By contrast, female chimeras generated by blastocyst injection of $H d h^{-/-}$ES cells were able to mate successfully with wild-type males, because two transmitted the $H d h$ mutation to their progeny. Five male and two female chimeras showed a characteristic set of abnormal motor traits, notably clasping of the forelimbs and hindlimbs and curling of the body during the clasping, beginning at weaning (4 weeks of age). In addition, four of these chimeras, beginning at 4 weeks, could not grasp or support themselves well on an elevated wire rod, and, when placed on a wire cage that then was rotated slowly, the chimeras invariably fell off the cage (whereas control animals did not). By 20 weeks of age all seven of these chimeras failed the rod grasping and rotating cage grasping tests. A simple gait analysis that used inked hindpaws did not, however, reveal differences from controls. The abnormal animals also tended to be attacked and wounded by their littermates when housed with them, implying the symptomatic chimeric mice were less able to defend themselves.

Of the seven animals that exhibited the suite of severe behav- 


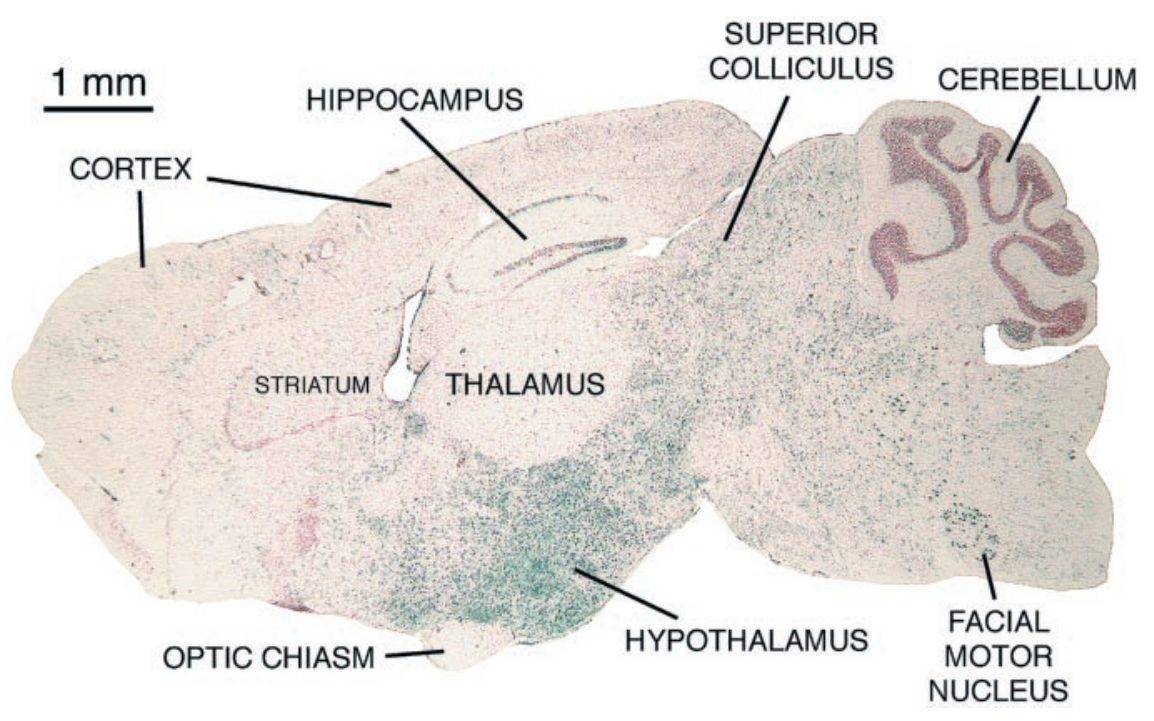

Figure 1. Image of a sagittal section from one of the chimeric mice created by blastocyst injection of $H d h^{-/-}$ ES cells, stained to reveal the location of the X-galpositive $H d h^{-1-}$ ES cell progeny that have colonized the brain. The tissue was counterstained with neutral red. This animal (ES13) was among those chimeric mice possessing $H d h^{-/-}$cells that were killed before 1 year of age because of signs of morbidity. The green-blue $\mathrm{X}$-gal labeling shows that $H d h^{-1-}$ cells are found throughout brain but are most abundant in hippocampus, preoptic area, hypothalamus, midbrain, and hindbrain.

cryostat sections. Six of the chimeric mice that survived slightly beyond 1 year without showing the suite of severe behavioral abnormalities were perfused transcardially with fixative, as described in Materials and Methods, and the brains were processed histologically as free-floating slide-mounted sections. chimeric contribution $<45 \%$ (based on coat color; Table 1). Among the three mice with a chimeric contribution $\geq 45 \%$ that did not show the suite of severe behavioral/motor abnormalities, two in fact showed mild clasping (one mouse with $60 \%$ coat color chimerism and one with $65 \%$ ) but were unaffected in the other tests (Table 1). One further chimeric mouse (with $40 \%$ coat color chimerism) also had a mild clasping tendency but was unaffected in the other tests as well (Table 1). The data therefore suggest that the magnitude of the overall $\mathrm{Hdh}^{-1-}$ contribution, as inferred from coat color, was associated with an increased likelihood of motor abnormalities, either severe or slight. To assess this apparent association, we assigned a score of 0 for no motor deficit; a 1 for a slight clasping defect; a 2 for showing clasping, poor rod grasping, and poor rotating cage grasping by 20 weeks; and a 3 for showing clasping, poor rod grasping, and poor rotating cage grasping by 4 weeks. With the use of this motor scoring scale, the percentage of ES cell contribution indicated by coat color is correlated significantly $(r=0.73)$ with the motor deficit. Nonetheless, it is evident that the severity of the behavioral abnormalities was not predicted inexorably by the percentage of coat color chimerism. For example, severe motor abnormalities were observed in one animal with only $30 \%$ coat color chimerism but were absent in three with $\geq 45 \%$ coat color chimerism. Such deviations from a strictly linear relationship between coat color chimerism and the magnitude of the motor abnormalities may have occurred because the extent of colonization by $\mathrm{Hdh}^{-1-}$ cells of the key neural and/or the key extraneural regions that were needed to produce the observed suite of behavioral abnormalities was not reflected accurately in all cases by the abundance of $H d h^{-1-}$ cells in the coat. Such an explanation is consistent with the evidence that the relative colonization of bodily tissues by the genotypically different lineages comprising a chimeric animal can differ from tissue to tissue and animal to animal (Le Dourain and McLaren, 1984; Goldowitz et al., 1992; Kuan et al., 1997).

The seven mice showing the suite of behavioral abnormalities also exhibited severe weight loss and severe hypoactivity by 6-9 months of age and were killed at that time. The brains of four were immersion fixed overnight, as described in Materials and Methods, and stored frozen until processed as slide-mounted

\section{Blastocyst injection chimeras: Histological analysis of Hdh $^{-/-}$chimeras}

The 10 chimeras and two B6 control mice were sectioned and analyzed histologically and histochemically. The brains of the chimeras appeared normal in gross morphology, cytoarchitecture, regional neuronal abundance, and ventricular outline (Fig. 1). The brains of the chimeras, however, typically were slightly smaller than those of the controls. In the 10 chimeras, numerous $\mathrm{X}$-gal-labeled cells derived from the $H d h$ nullizygous ES cells injected at the blastocyst stage were found throughout the brain (Table 2; Fig. 1). No systematic differences were observed in the distribution of these $H d h^{-/-}$cells for the three injected lines of $H d h^{-/-}$embryonic stem cells (A, B, and I). Side-by-side comparisons of X-gal-labeled tissue and huntingtin-labeled tissue showed that regions rich in X-gal-labeled cells were poor in huntingtin-labeled cells, thereby confirming that X-gal-labeled cells were indeed $H d h^{-1-}$. This was particularly evident in the cornu ammonis of the hippocampus, in which alternating bands of $\mathrm{X}$-gal-labeled and huntingtin-labeled neurons could be observed (Fig. 2). No X-gal-labeled cells were observed in the B6 control mice. Although X-gal-labeled $H d h^{-1-}$ cells were found throughout the brain of all 10 chimeric mice, the $H d h^{-1-}$ cells tended to be relatively scarce in the telencephalon (except for the hippocampus, in which they were consistently present), mainly absent from the thalamus and Purkinje cell layer of the cerebellum, and abundant in the epithalamus, preoptic region, hypothalamus, midbrain, granule cell layer of the cerebellum, and hindbrain (Table 2; Fig. 3). The abundance of these cells in these regions, however, varied from case to case. For example, in some cases $H d h^{-1-}$ cells in hypothalamus and brainstem made up at least $50 \%$ of the cells, which was especially evident for the motoneuron pools in the case of the brainstem, whereas in others $H d h^{-/-}$ cells made up no more than $\sim 25 \%$ of the cells in hypothalamus or brainstem (Table 2). In the latter cases $\mathrm{Hdh}{ }^{-1-}$ cells were nearly absent in the cerebral cortex, basal ganglia, and thalamus, whereas even in the former they typically did not include $>10 \%$ 


\begin{tabular}{|c|c|c|c|c|c|c|c|c|c|c|}
\hline Animal & ES1 & ES2 & ES3 & ES7 & ES8 & ES9 & ES10 & ES11 & ES12 & ES13 \\
\hline ES clone & I & I & I & B & I & I & B & A & $\mathrm{I}$ & A \\
\hline Percentage of KO by coat & 60 & 65 & 40 & 30 & 30 & 50 & 60 & 45 & 30 & 50 \\
\hline Age at death & 13 months & 13 months & 13 months & 13 months & 13 months & 13 months & 6 months & 9 months & 8 months & 9 months \\
\hline Behavioral abnormalities & Slight clasping & Slight clasping & None & None & None & None & $\begin{array}{l}\text { Severe by } \\
4 \text { weeks }\end{array}$ & $\begin{array}{l}\text { Severe by } \\
20 \text { weeks }\end{array}$ & $\begin{array}{l}\text { Severe by } \\
20 \text { weeks }\end{array}$ & $\begin{array}{r}\text { Severe by } \\
4 \text { weeks }\end{array}$ \\
\hline \multicolumn{11}{|l|}{ KO cell abundance } \\
\hline Neocortex & - & + & + & - & + & - & - & + & - & + \\
\hline Hippocampus & ++ & ++ & +++ & + & +++ & ND & + & +++ & - & + \\
\hline Striatum & ++ & ++ & + & + & + & - & + & ++ & - & ++ \\
\hline Globus pallidus & - & - & - & - & - & - & - & + & - & ++ \\
\hline Thalamus & - & - & - & - & - & - & - & - & - & - \\
\hline Hypothalamus & ++ & +++ & +++ & +++ & +++ & ++ & ++++ & ++++ & + & ++++ \\
\hline Midbrain & ++ & +++ & ++ & ++ & ++ & ++ & +++ & ++++ & + & ++++ \\
\hline Cerebellar GCL & +++ & ++++ & ++ & +++ & ++ & ++ & ++ & ++ & +++ & + \\
\hline Cerebellar PCL & - & - & - & - & - & - & - & - & - & - \\
\hline Brainstem motoneurons & +++ & +++ & +++ & +++ & ++ & ++ & ++++ & ++++ & + & ++++ \\
\hline Hindbrain & ++ & ++ & ++ & ++ & ++ & ++ & +++ & +++ & + & +++ \\
\hline
\end{tabular}

,$-<1 \% \mathrm{KO}$ cells;,$+=1-10 \% \mathrm{KO}$ cells,$++=11-25 \% \mathrm{KO}$ cells $;+++,=26-50 \% \mathrm{KO}$ cells;,$++++>50 \% \mathrm{KO}$ cells; $\mathrm{ND}, \mathrm{Not}$ done.

$\mathrm{KO}, \mathrm{Hdh}^{-1-}$; GCL, granule cell layer; PCL, Purkinje cell layer.

of telencephalic and thalamic cells. By contrast, in the nonchimeric ROSA26 control mice, X-gal labeling was observed in all cells throughout the brain, consistent with the previous observations of others (Friedrich and Soriano, 1991; Goldowitz et al., 2000).

Because the $\mathrm{X}$-gal reaction product in the chimeric mice in many cases clearly could be localized to neurons (particularly in the case of large neurons for which the shape was unmistakable because the X-gal reaction product followed the cellular outline; Fig. 3), our results show that $H d h^{-/-}$neurons can survive in the chimeric brain for $>1$ year and that, up to an abundance of $50 \%$ $H d h^{-/-}$cells in midbrain and hindbrain, brain development seems normal. Three of the four chimeras showing the behavioral abnormalities and morbidity that were examined histologically, however, were enriched in hypothalamic and brainstem $\mathrm{Hdh}^{-1-}$ cells (estimated to be $50-75 \%$ for the brainstem motoneuron pools, for example, in these mice). By contrast, none of the chimeric mice who showed no morbidity up to 1 year after birth and who were examined histologically possessed $>50 \% \mathrm{Hdh}$ knock-out cells in both hypothalamus and motoneuron pools (Table 2). This suggests that $>50 \%$ colonization of hypothalamus and brainstem by $H d h^{-/-}$cells may have played a role in the behavioral abnormalities and morbidity observed in at least some chimeric animals.

We used various immunomarkers to assess the normalcy of brain functional architecture. In light of the prominent involvement of the basal ganglia in $\mathrm{HD}$, the possible effect of $\mathrm{Hdh}{ }^{-/-}$ cells on the striatum and its projection systems was of particular interest. Although the chimeric animals varied in their abundance of $H d h^{-1-}$ cells in the striatum (from negligible to $\sim 15 \%$ ), we observed no evident differences between chimeric mice and wildtype mice in the distribution or abundance of calbindincontaining projection neurons or parvalbumin-containing interneurons in the striatum (Figs. 4, 5), both of which are affected in HD (Kiyama et al., 1990; Harrington and Kowall, 1991). Additionally, the abundance of enkephalinergic striatal fibers in the globus pallidus and of substance P-containing fibers in the entopeduncular nucleus and substantia nigra appeared no different from those in the B6 control mice (see Fig. 4), suggesting further that striatal projection neurons, which are affected prominently in HD (Reiner et al., 1988; Albin et al., 1990a,b, 1992; Richfield et al., 1995; Sapp et al., 1995), were unaffected in the chimeric mice. Similarly, a high abundance of $H d h^{-1-}$ cells in the hypothalamus was not associated with any evident abnormality in the hypothalamic distributions of vasopressin, VIP, tyrosine hydroxylase, or NPY, and a prevalence of $H d h^{-/-}$neurons in brainstem motoneurons was not associated with any evident loss of choline acetyltransferase labeling of these neurons or any alteration in the abundance of these neurons (Figs. 6, 7). Consistent with the absence of any brain abnormalities, as assayed by neuropeptide or neurotransmitter-related enzyme content, neither immunolabeling for GFAP (see Figs. 5, 7) nor staining with fluoro-jade, a marker of neurodegenerative changes, revealed any signs of pathology in the chimeric brains. It is noteworthy that this was true for both the chimeras showing morbidity by $6-9$ months as well as those surviving with no signs of ill health until the time of death at $\sim 1$ year. By contrast, the hippocampus of the kainate-injected C57BL/6 mice showed large numbers of degenerating fluorojade-positive pyramidal neurons.

\section{DISCUSSION}

To understand better the significance of huntingtin in neuronal function, we overcame the embryonic lethality of homozygous knock-out of the HD gene homolog in mice by a chimeric strategy. Our findings reveal several important points regarding the role of huntingtin in neural development and neuronal survival, as discussed below.

\section{Comparison to previous findings by others}

Our failure to produce viable aggregation chimeras possessing cells with homozygous $H d h$ deletion may stem from the previously demonstrated role of huntingtin in the extraembryonic membranes, particularly those derived from trophectoderm, during early development (Dragatsis et al., 1998). The apparent participation of huntingtin in vesicular trafficking (DiFiglia et al., 1995; Sharp et al., 1995; Wood et al., 1996) may be important in 

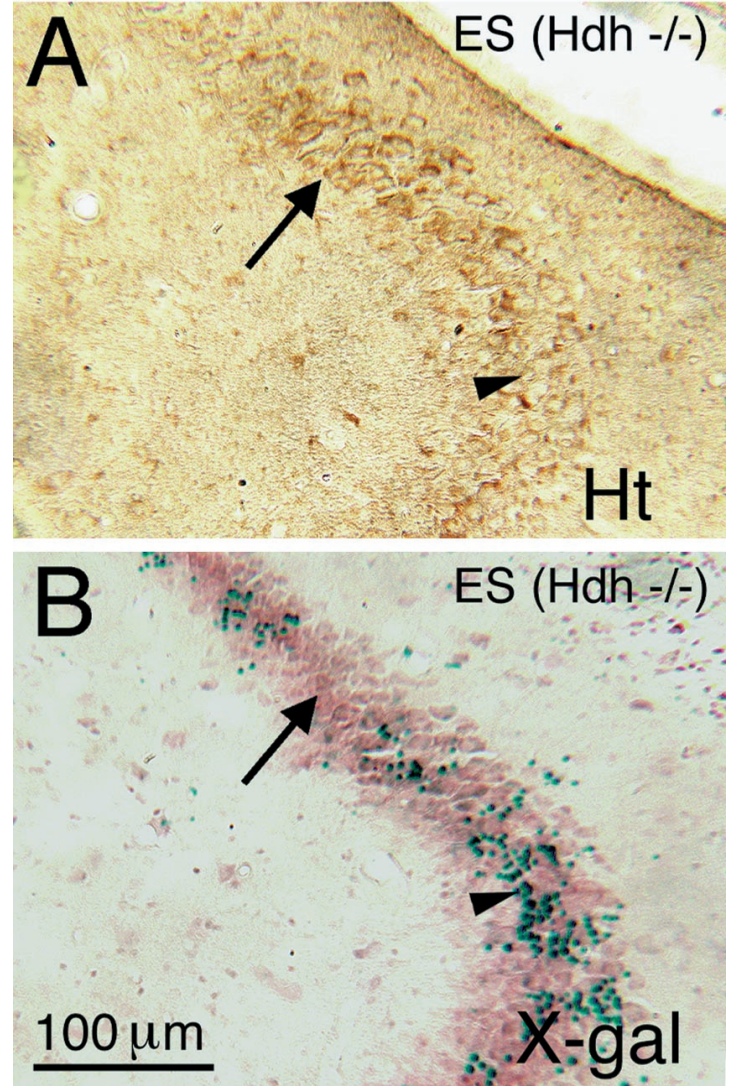

Figure 2. Image of CA2 in a transverse section from one of the chimeric mice created by blastocyst injection of $H d h^{-1-}$ ES cells, stained to reveal the localization of huntingtin-containing wild-type cells (visualized by DAB immunolabeling; $A$ ) and X-gal-positive ES cell progeny that have colonized the hippocampus $(B)$. The X-gal-labeled tissue also was counterstained with neutral red. This animal was among those that lived up to 1 year of age with no signs of morbidity. The green-blue X-gal labeling shows that $H d h^{-1-} \mathrm{CA} 2$ pyramidal cells in regions lacking in X-gal labeling are immunostained for huntingtin (arrow indicates a large cluster of huntingtin-labeled neurons). By contrast, regions of CA2 richly labeled for X-gal (arrowhead) are poor in or devoid of huntingtin immunolabeling.

the transport of nutrients across the extraembryonic membranes, and disruption of this function may be the basis of the embryonic lethality of homozygous huntingtin deletion (Dragatsis et al., 1998). Huntingtin with a polyglutamine expansion in the range causing HD does not disrupt this function critically, because humans with a homozygous HD mutation do not exhibit embryonic lethality (Wexler et al., 1987; Myers et al., 1989; Gusella and MacDonald, 1996) and because a transgene expressing huntingtin with such a polyglutamine expansion rescues $H d h$ null mice from embryonic lethality (Hodgson et al., 1999; Leavitt et al., 2000). Additionally, one normal huntingtin allele is sufficient in humans or mice for normal development and postpartum life (Ambrose et al., 1994; Duyao et al., 1995; Nasir et al., 1995; Zeitlin et al., 1995; Persichetti et al., 1996). By contrast, our inability to produce viable chimeras containing $H d h^{-/-}$cells by using the method of early embryo aggregation suggests that even limited colonization of the extraembryonic membranes by $H d h^{-1-}$ cells may impair their function so as to be lethal to the developing embryo. Note, however, that we did not investigate the stage beyond which our aggregation chimeras with $H d h^{-1-}$ cells failed to develop. Deficiencies in huntingtin also are known to promote defects in

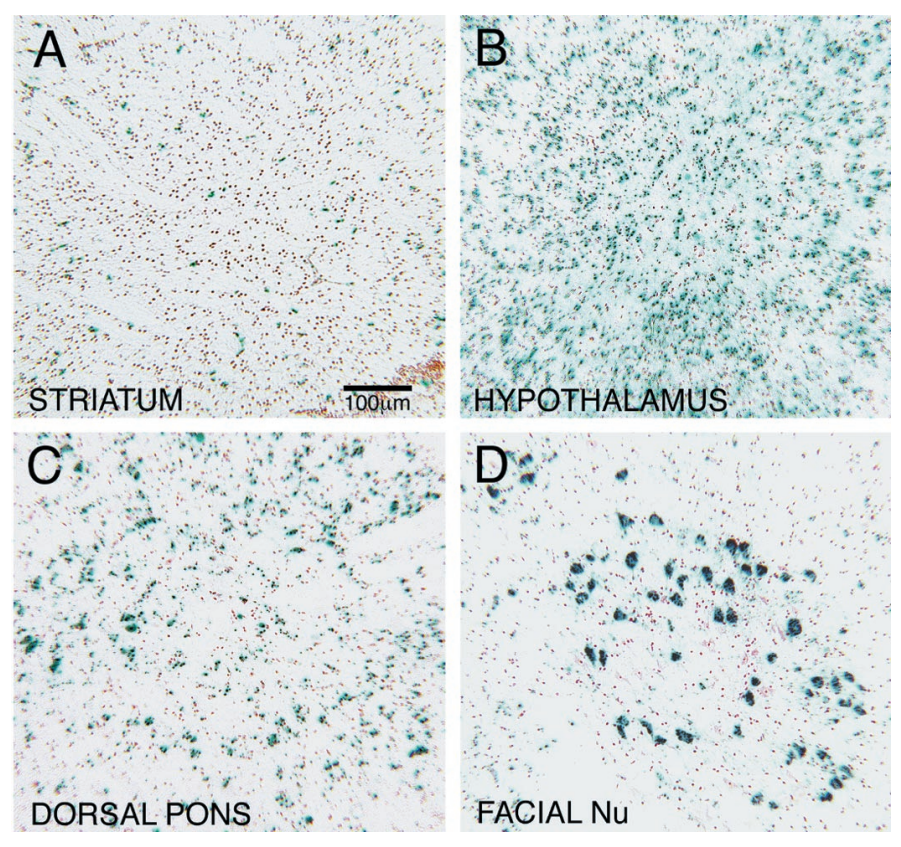

Figure 3. High-magnification images showing the distribution and abundance of $H d h^{-1-}$ cells in several brain regions in the same chimeric mouse created by blastocyst injection of $H d h^{-1-}$ ES cells, as shown in Figure 1. The green-blue X-gal labeling shows that $H d h^{-1-}$ cells are scarce in striatum $(A)$ and highly abundant in the preoptic region $(B)$ and dorsal pons $(C)$. The image presented in $D$ shows that the vast majority of the neurons in the facial nucleus in this case was $H d h^{-1-}$. The section from which these images were taken had been counterstained lightly with neutral red.

proliferation (White et al., 1997), and it may be that such a defect placed the $4-8 H d h^{-1-}$ cells from the $H d h$ knock-out strain at a disadvantage relative to the $4-8 H d h^{+/+}$cells from the wild-type strain in their ability to proliferate and populate chimeras after aggregation.

The results of our studies on chimeras created by the blastocyst injection method, in which the lethal effects of $H d h^{-/-}$cells in the extraembryonic membranes are avoided (Dragatsis et al., 1998), demonstrate that $H d h^{-1-}$ cells can participate in the normal formation of the brain and can develop into neurons with normal morphology and transmitter content that survive for $>1$ year with no evident signs of brain pathology. These results extend on recent data showing that $H d h^{-1-}$ ES cells transformed into a neuronal phenotype in vitro can survive for several weeks and show typical neuronal electrophysiological traits (Metzler et al., 1999). We did, however, find evidence that $H d h^{-1-}$ cells do not colonize equally and/or thrive in all brain areas. In particular, we observed that neurons and/or glia derived from the $H d h$ ES cells tended to colonize preferentially the hypothalamus, midbrain, granule cell layer of cerebellum, and hindbrain, with only a sparse occupancy of cerebral cortex, basal ganglia, thalamus, and Purkinje cell layer of cerebellum. Our studies of lacZ expression in control ROSA26 mice indicate that this paucity of $\mathrm{X}$-gal-labeled cells in some brain regions in the blastocyst injection chimeras is not a false negative stemming from poor lac $Z$ expression by ES cells that had colonized these regions. Thus our findings raise either of two possibilities. First, it may be that some peculiarity of our ES cells independent of their Hdh genotype resulted in this differential colonization. Although there is evidence that ES cells can show a tendency to colonize CNS differ- 

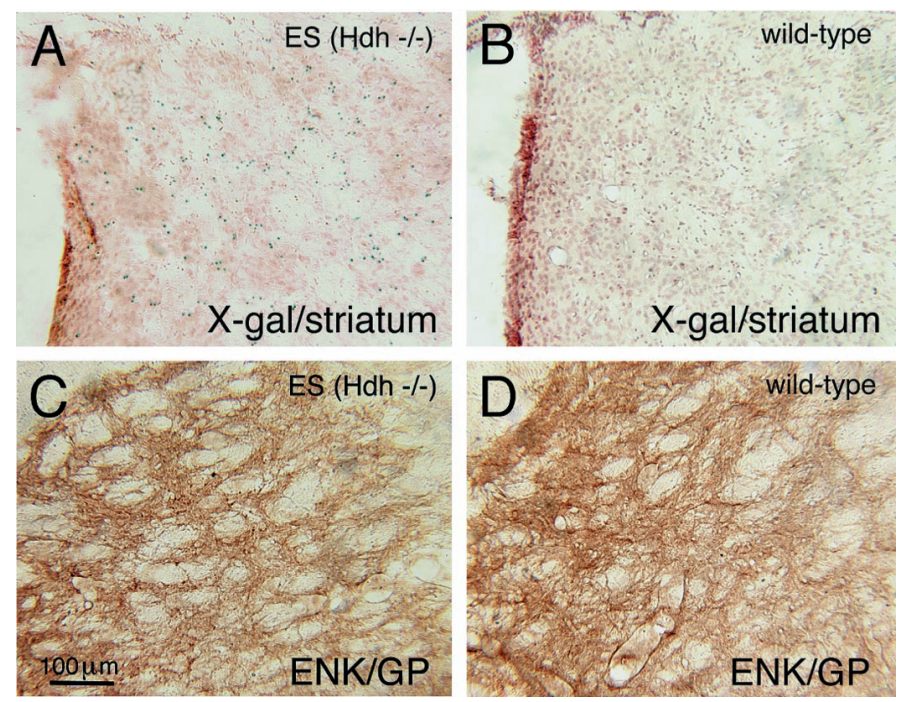

Figure 4. High-magnification images of transverse sections through dorsomedial striatum showing the distribution and abundance of $H d h$ cells (as visualized by X-gal labeling, followed by a light neutral red counterstain) in the striatum of a chimeric mouse created by blastocyst injection of $H d h^{-1}$ ES cells. Shown is the striatum of a chimeric mouse, who displayed no ill health up to 1 year of age $(A)$, compared with the striatum of a wild-type mouse in which no $H d h^{-1-}$ cells are present $(B)$. $C, D$, The presence of $H d h^{-/-}$cells in the striatum of the chimeric mouse shown in $A$ has not produced any evident abnormality in the enkephalinergic striatal output fibers (ENK; visualized by DAB immunolabeling) within the ipsilateral globus pallidus $(G P)$ of the chimeric mouse $(C)$. Medial is to the left and dorsal to the top in all images.
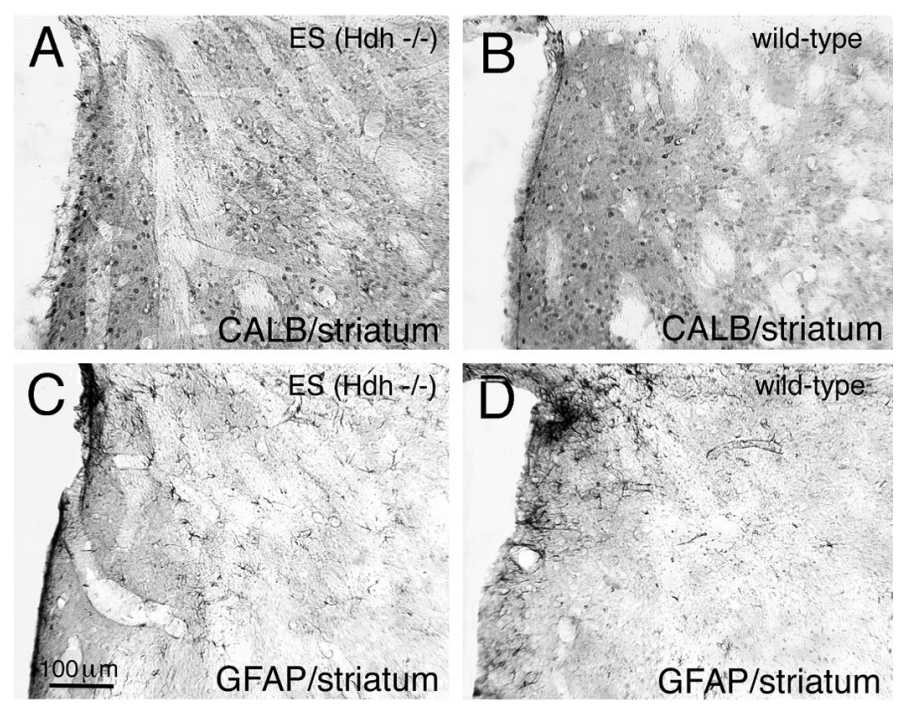

Figure 5. High-magnification images of transverse sections through dorsomedial striatum of the same chimeric and wild-type animals as shown in Figure 4. The presence of $H d h^{-1-}$ cells in the striatum of the chimeric mouse has not produced any evident abnormality in the labeling of calbindergic striatal perikarya $(A, B)$ or any evidence of neuropathology in the striatum, as shown by the absence of any upregulation of glial fibrillary acid protein $(G F A P)$ in the striatum $(C, D)$. Medial is to the left and dorsal to the top in all images.

entially in chimeric animals (Kuan et al., 1997), the pattern has been found to vary randomly from one chimeric animal to the next even for the same ES cell line. By contrast, we observed the same consistent pattern of preferential hypothalamic, midbrain,
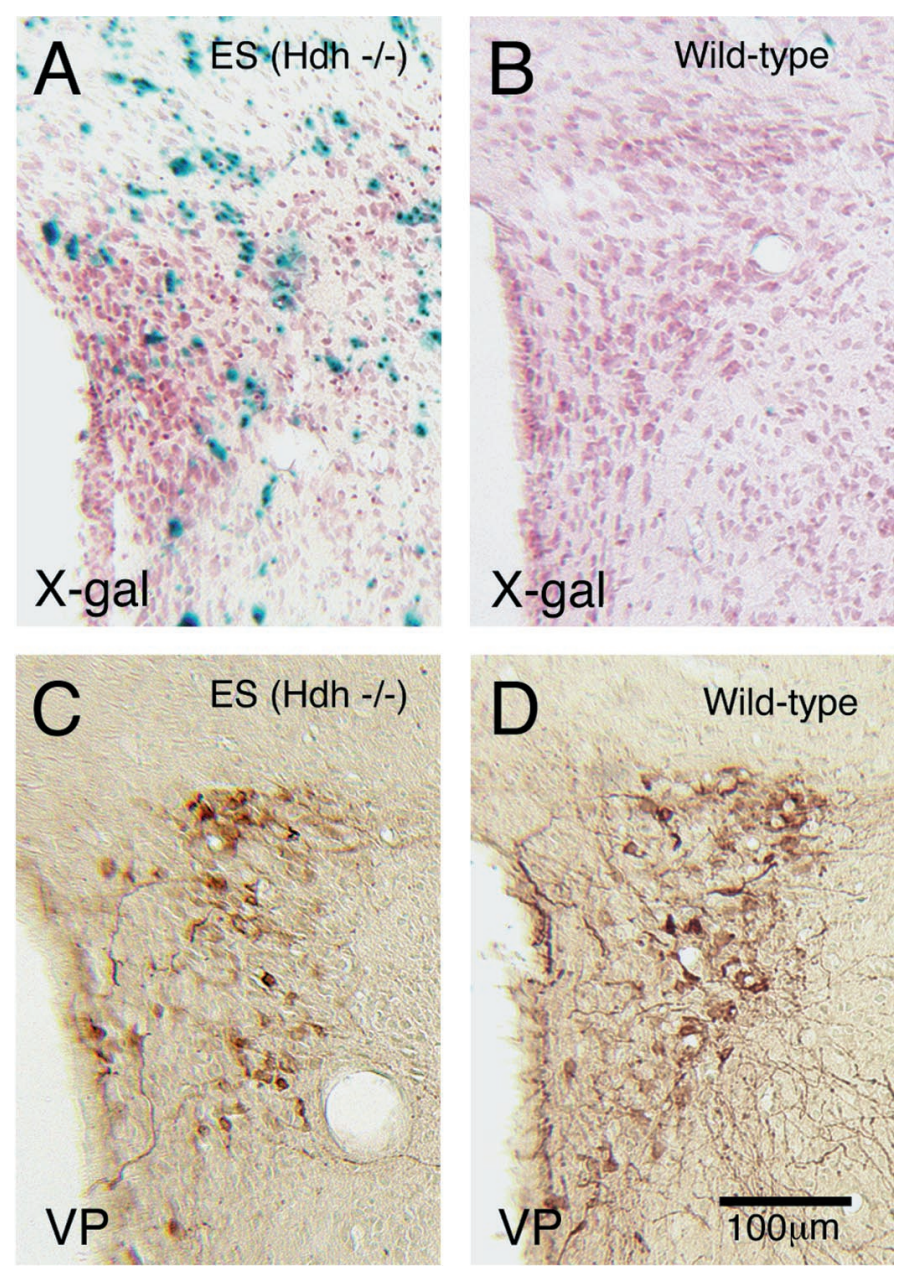

Figure 6. High-magnification images of transverse sections through the paraventricular nucleus of the hypothalamus showing the distribution and abundance of $H d h^{-1-}$ cells in striatum of a chimeric mouse created by blastocyst injection of $H d h^{-1-}$ ES cells (ES8). Shown is the striatum of a chimeric mouse, who displayed no ill health up to 1 year of age $(A)$, compared with the paraventricular nucleus of a wild-type mouse in which no $H d h^{-1-}$ cells are present $(B)$. The $H d h^{-1-}$ cells in $A$ are visualized by X-gal labeling, and neuronal cytoarchitecture in both $A$ and $B$ is visualized by neutral red counterstaining. $C, D$, The presence of $H d h$ cells in the paraventricular nucleus of the chimeric mouse shown in $A$ has not produced any evident abnormality in the vasopressinergic $(V P)$ neurons (visualized by DAB immunolabeling) of the ipsilateral paraventricular nucleus of the chimeric mouse. Medial is to the left and dorsal to the top in all images.

and hindbrain colonization by ES cells for each of our three independently derived lines of $H d h^{-1-}$ ES cells, and the consistency of preferential colonization was greater than reported to occur for a single ES cell type (Kuan et al., 1997). Thus the second, and more likely, interpretation of the consistent paucity of $H d h^{-1-}$ ES cell progeny in cerebral cortex, basal ganglia, thalamus, and the Purkinje cell layer of cerebellum is that huntingtin may be needed for cells to migrate to, proliferate in, and/or survive extensively within these regions.

Thus individual cells in many brain regions may not need huntingtin to differentiate into neurons that survive and function normally, whereas in other brain regions many cells may need to express normal levels of huntingtin if development is to proceed normally for that region. For example, brain development may 

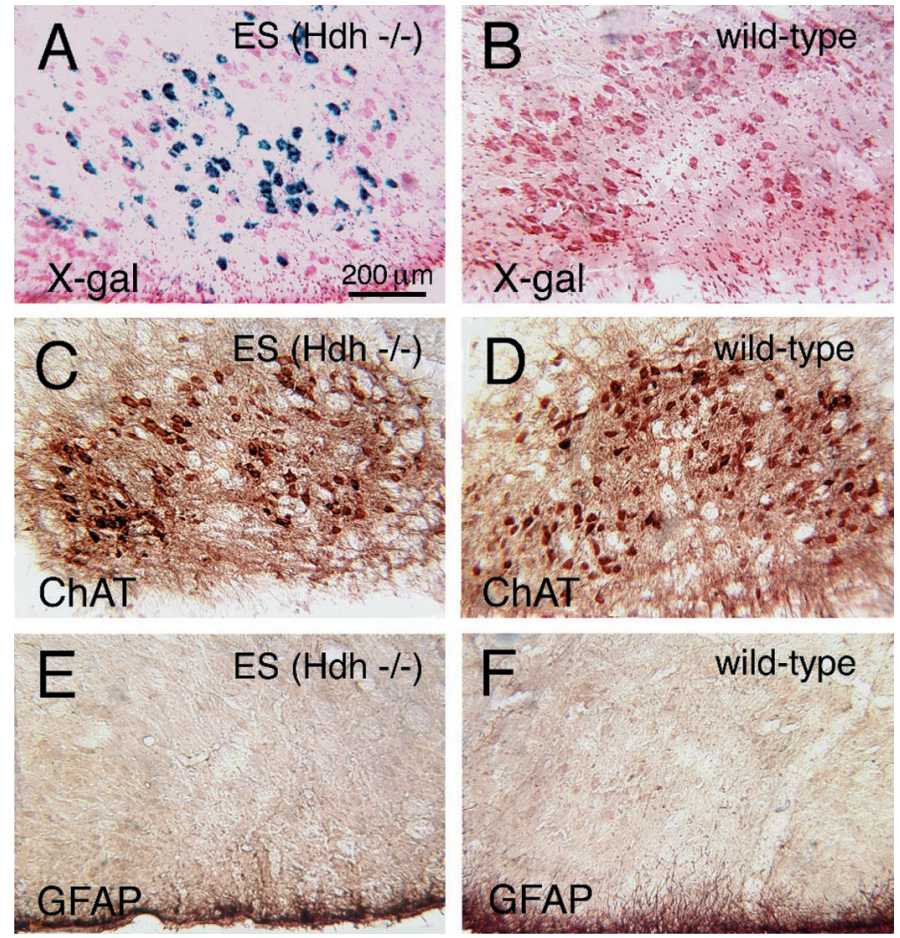

Figure 7. High-magnification images of transverse sections through pons showing the distribution and abundance of $H d h^{-1-}$ cells in the facial nucleus in a chimeric mouse created by blastocyst injection of $H d h^{-1-}$ ES cells. Shown is the facial nucleus in a chimeric mouse, who displayed no ill health up to 1 year of age $(A)$, compared with facial nucleus of a wild-type mouse in which no $H d h^{-1-}$ cells are present $(B)$. The $H d h^{-1}$ cells in $A$ are visualized by $\mathrm{X}$-gal labeling, and neuronal cytoarchitecture in both $A$ and $B$ is visualized by neutral red counterstaining. $C, D$, The presence of $H d h^{-1-}$ cells in the facial nucleus of the chimeric mouse shown in $A$ has not produced any evident abnormality in the facial motoneurons (visualized by DAB immunolabeling for choline acetyltransferase) within the ipsilateral facial nucleus of the chimeric mouse. High-magnification images of transverse sections through facial nucleus of the same chimeric and wild-type animals as shown in $A$ and $B$ reveal that the presence of $H d h^{-1-}$ cells in the facial nucleus of the chimeric mouse has not produced any upregulation of GFAP in the facial nucleus $(E, F)$. Medial is to the left and dorsal to the top in all images.

have been seemingly normal even in the hypothalamus and brainstem of chimeras in which $\geq 50 \%$ of the resident neurons were $H d h^{-/-}$, because huntingtin plays no major role in the development and/or functioning of these regions. By contrast, huntingtin clearly seems to be critical for cortical and striatal development, because mouse mutants in which huntingtin is expressed at onethird of wild-type levels exhibit defective neurogenesis, profound malformations of cortex and striatum, ventricular enlargement, and agenesis of fiber tracts (White et al., 1997). Consistent with a regionally differential role of huntingtin in neural development, cortex and striatum express higher levels of huntingtin than do hypothalamus and brainstem (Li et al., 1993; Landwehrmeyer et al., 1995; Sharp et al., 1995; Bhide et al., 1996; Sapp et al., 1997; Fusco et al., 1999). The absence of forebrain developmental abnormalities in our chimeras with $H d h^{-/-}$cells may be a consequence of the relatively low colonization of cortex and striatum by $\mathrm{Hdh}{ }^{-/-}$cells. This low colonization could stem from impaired proliferation of $H d h^{-1-}$ cells during development or from the death of these cells. Note, however, that we did not see signs that cell loss had occurred recently in cortex, basal ganglia, thalamus, or Purkinje cell layer in the chimeras. Thus if the paucity of $H d h^{-1-}$ neurons in telencephalon, thalamus, and Purkinje cell layer reflects their failure to survive in these regions, this loss had to occur at an early enough point in development for the $H d h^{-1-}$ neuroblasts to have been replaced by wild-type neuroblasts. It is also possible that the reduced brain size seemingly typical of the chimeras masked evidence of early neuron loss.

The chimeric mice created by the blastocyst injection method showed a reduced body size proportional to the bodily abundance of $\mathrm{Hdh}^{-1-}$ cells implied by coat color, and the chimeras most enriched in $H d h^{-1-}$ cells additionally tended to show motor abnormalities and morbidity before 1 year of age. The basis of these abnormalities is uncertain, but the findings do suggest that an excess of $H d h^{-/-}$in some key neural (or extraneural) regions compromises their function in some currently unknown way. For example, the reduced body size characteristic of the blastocyst injection chimeras could stem from abnormalities in feeding and growth regulation because of colonization by $\mathrm{Hdh}{ }^{-/-}$cells of neural and extraneural regions critical to these processes. The mice with the behavioral abnormalities and premature morbidity tended to be those in which $H d h^{-1-}$ cells in general, as inferred from coat color, made up $\geq 45 \%$ of the cells in the body. Given, however, that colonization of any individual tissue by $\mathrm{Hdh} \mathrm{H}^{-/-}$ cells may have deviated from the degree of colonization suggested by coat color (Le Dourain and McLaren, 1984; Goldowitz et al., 1992), the bodily tissues critical to the occurrence of the abnormalities may not have been colonized highly in all chimeras that were $\geq 45 \% \mathrm{Hdh}^{-1-}$ by coat color, or they may have, in fact, been colonized highly in chimeras with $<45 \% \mathrm{Hdh}^{-1-}$ by coat color. This may explain the absence of abnormalities in some chimeras $\geq 45 \% \mathrm{Hdh}^{-1-}$ by coat color and their presence in one with $<45 \% \mathrm{Hdh}^{-/-}$by coat color. The identity of the neural or extraneural regions for which the high colonization by $H d h^{-/-}$ cells is critical to the occurrence of the behavioral/motor abnormalities in the blastocyst injection chimeras is uncertain. In three of the four mice with the behavioral abnormalities that were examined histologically, $>50 \%$ of the neurons in hypothalamus and brainstem motoneuron pools were found to be $\mathrm{Hdh}{ }^{-1-}$, suggesting their involvement in the abnormalities in at least some chimeric mice. The precise basis of the behavioral/motor abnormalities, however, will require focused study of the relationship between the percentage of colonization of various bodily tissues and the abnormalities in a larger number of animals than was possible in the present study.

Finally, the infertility of the male blastocyst injection chimeras may be behavioral, or it also could be attributable to problems in the testes. In this light, it is interesting that mice with a conditional deletion of $H d h$ under the control of a calmodulindependent kinase II (CaMKII) promoter (CaMKII is expressed late in development and thereby allows these mice to evade the embryonic lethality of homozygous $H d h$ knock-out) are infertile because of a very low sperm count (Dragatsis et al., 2000). Similarly, mice possessing transgenic insertions of CAGexpanded forms of the human HD gene against a nullizygous $H d h$ background have been shown to undergo spermatocyte degeneration (Leavitt et al., 2000). By contrast, Hdh ${ }^{+/-}$males mated with wild-type females can pass on the Hdh mutation to their offspring, implying that sperm (which are haploid) lacking huntingtin can survive and fertilize eggs (Duyao et al., 1995; Nasir et al., 1995; Zeitlin et al., 1995). Thus huntingtin may not be needed for the viability of sperm, but it may play some critical role in the 
viability of spermatogonia or primary spermatocytes or in spermatogenesis itself.

\section{Implications for the pathogenesis of HD}

A gain of function associated with the HD mutation is the aggregation of the N-terminal fragment of mutated huntingtin within neuronal nuclei and cytoplasm (DiFiglia et al., 1997; Li and Li, 1998; Martindale et al., 1998; Gutekunst et al., 1999; Maat-Schieman et al., 1999). Although considerable attention has focused on the possibility that these aggregates are a key pathogenic event in HD (Davies et al., 1997; DiFiglia et al., 1997; Kim and Tanzi, 1998; Saudou et al., 1998; Sisodia, 1998), the means by which they might lead to neuronal death remains uncertain (Cha et al., 1998; Hackham et al., 1998; Sisodia, 1998). The possibility that the aggregates may act, at least in part, by inactivating both mutant and normal huntingtin has been raised by recent evidence that the aggregates that form in HD and in transgenic animal models of $\mathrm{HD}$ can sequester normal-length polyglutaminecontaining proteins, including huntingtin (Cha et al., 1999; Narain et al., 1999; Preisinger et al., 1999; Wheeler et al., 1999; Cattaneo et al., 2001). This has led to the recent suggestion that the HD mechanism of action might receive a contribution from a late-onset inactivation of normal huntingtin (Cattaneo et al., 2001). Such a possibility is consistent with the finding that huntingtin appears to exert an anti-apoptotic effect in cultured striatal neurons subjected to serum deprivation or metabolic stress (Rigamonti et al., 2000). Our finding that neurons that are $H d h^{-1-}$ appear to be defective in their ability to colonize cortex, striatum, thalamus, and Purkinje cell layer of cerebellum suggests that neurons in these regions may require huntingtin more critically to develop and/or survive normally. If, in fact, these neuron types require huntingtin for long-term survival in adult brain, the fact that they are all affected in HD (Roos, 1986) would be consistent with a contribution of late-onset inactivation of normal huntingtin to HD pathogenesis. Nonetheless, this possibility would leave unexplained why striatal neurons are so much more vulnerable and cortical neurons somewhat more vulnerable than thalamic neurons and Purkinje cells in HD (Roos, 1986). It may be that striatal and, less so, cortical neurons more greatly require huntingtin for survival than do thalamic neurons and Purkinje cells. Such a possibility is consistent with the preferential morbidity of $H d h^{-1-}$ neurons in cortex and striatum in postweaning mice in which the $H d h$ knock-out is expressed beginning late in embryonic development (Dragatsis et al., 2000). On the other hand, it is also possible that inactivation of normal huntingtin plays little, if any, role in HD pathogenesis.

\section{REFERENCES}

Albin RL, Tagle DA (1995) Genetics and molecular biology of Huntington's disease. Trends Neurosci 18:11-14.

Albin RL, Reiner A, Anderson KD, Penney JB, Young AB (1990a) Striatal and nigral neuron subpopulations in rigid Huntington's disease: implications for the functional anatomy of chorea and rigidity-akinesia. Ann Neurol 27:357-365.

Albin RL, Young AB, Penney JB, Handelin B, Balfour R, Anderson KD, Markel DS, Tourtellotte WW, Reiner A (1990b) Abnormalities of striatal projection neurons and $N$-methyl-D-aspartate receptors in presymptomatic Huntington's disease. N Engl J Med 332:1293-1298.

Albin RL, Reiner A, Anderson KD, Dure IV LS, Handelin B, Balfour R, Whetsell Jr WO, Penney JB, Young AB (1992) Preferential loss of striato-external pallidal projection neurons in presymptomatic Huntington's disease. Ann Neurol 31:425-430.

Ambrose CM, Duyao MP, Barnes G, Bates GP, Lin CS, Srinidhi J, Baxendale S, Hummerich H, Lehrach H, Atherr M, Wasmuth J, Buck- ler A, Church D, Housman D, Berks M, Micklem G, Durbin R, Dodge A, Read A, Gusella J, MacDonald ME (1994) Evidence against simple inactivation due to an expanded CAG repeat. Somat Cell Mol Genet 20:27-38.

Anderson KD, Reiner A (1990) The extensive co-occurrence of substance $\mathrm{P}$ and dynorphin in striatal projection neurons: an evolutionarily conserved feature of basal ganglia organization. J Comp Neurol 295:339-369.

Anderson KD, Reiner A (1991) Immunohistochemical localization of DARPP-32 in striatal projection neurons and striatal interneurons: implications for the localization of D1-like dopamine receptors on different types of striatal neurons. Brain Res 568:235-243.

Armstrong WE, Smith BN, Tian M (1994) Electrophysiological characteristics of immunochemically identified oxytocin and vasopressin neurones in vitro. J Physiol (Lond) 475:115-128.

Beddington RSP, Robertson EJ (1989) An assessment of the developmental potential of embryonic stem cells in the midgestation embryo. Development 105:733-737.

Bessert DA, Gutridge KL, Dunbar JC, Carlock LR (1995) The identification of a functional nuclear localization signal in the Huntington's disease protein. Mol Brain Res 33:165-173.

Bhide PG, Day M, Sapp E, Schwarz C, Sheth A, Kim J, Young AB, Penney J, Golden J, Aronin N, DiFiglia M (1996) Expression of normal and mutant huntingtin in the developing brain. J Neurosci 16:5523-5535.

Bruyn GW, Went LN (1986) Huntington's chorea. Handbook Clin Neurol 5:267-313.

Cattaneo E, Rigamonti D, Goffredo D, Zuccato C, Squitieri F, Sipione S (2001) Loss of normal huntingtin function: new developments in Huntington's disease research. Trends Neurosci 24:182-188.

Cha JHJ, Kosinski CM, Kerner JA, Alsdorf SA, Mangiarini L, Davies SW, Penney JB, Bates GP, Young AB (1998) Altered brain neurotransmitter receptors in transgenic mice expressing a portion of an abnormal human Huntington disease gene. Proc Natl Acad Sci USA 95:6480-6485.

Cha JHJ, Chung WM, Frey AS, Menon AS, Vonsattel JPG, Li XJ, Ona VO, Li M, Andrews LJ, Khan SQ, Stieg PE, Yuan J, Penney JB, Friedlander RM, Young AB (1999) Caspase-1 inhibition delays receptor changes and neuronal intranuclear inclusions, and corrects aberrant huntingtin cleavage in transgenic Huntington's disease mice. Soc Neurosci Abstr 25:542.

Chen Q, Veenman CL, Knopp K, Yan Z, Medina L, Song WJ, Surmeier DJ, Reiner A (1997) Evidence for the preferential localization of GluR1 subunits of AMPA receptors to the dendritic spines of medium spiny neurons in rat striatum. Neuroscience 83:749-761.

Crawley JN (1999) Behavioral phenotyping of transgenic and knock-out mice: experimental design and evaluation of general health, sensory functions, motor abilities, and specific behavioral tests. Brain Res 835:18-26.

Davies SW, Turmaine M, Cozens BA, DiFiglia M, Sharp AH, Ross CA, Scherzinger E, Wanker EE, Mangiarini L, Bates GP (1997) Formation of neuronal intranuclear inclusions underlies the neurological dysfunction in mice transgenic for the HD mutation. Cell 90:537-548.

De La Monte SM, Vonsattel JP, Richardson Jr EP (1988) Morphometric demonstrations of atrophic changes in the cerebral cortex, white matter and neostriatum in Huntington's disease. J Neuropathol Exp Neurol 44:516-525.

DiFiglia M, Sapp E, Chase K, Schwarz C, Meloni A, Young C, Martin E, Vonsattel JP, Carraway R, Reeves SA, Boyce FM, Aronin N (1995) Huntingtin is a cytoplasmatic protein associated with vesicles in human and rat brain neurons. Neuron 14:1075-1081.

DiFiglia M, Sapp E, Chase KO, Davies SW, Bates GP, Vonsattel JP, Aronin N (1997) Aggregation of huntingtin in neuronal intranuclear inclusions and dystrophic neurites in brain. Science 277:1990-1993.

Dragatsis I, Efstratiadis A, Zeitlin S (1998) Mouse mutant embryos lacking huntingtin are rescued from lethality by wild-type extraembryonic tissues. Development 125:1529-1539.

Dragatsis I, Levine M, Zeitlin S (2000) Inactivation of the mouse Huntington's disease gene in the brain and testis results in progressive neurodegeneration and sterility. Nat Genet 26:300-306.

Duyao MP, Auerbach AB, Ryan A, Persichetti F, Barnes GT, McNeil SM, Ge P, Vonsattel JP, Gusella JF, Joyner AL, MacDonald ME (1995) Inactivation of the mouse Huntington's disease gene homolog Hdh. Science 269:407-410.

Elmquist JK, Elias CF, Saper CB (1999) From lesions to leptin: hypothalamic control of food intake and body weight. Neuron 22:221-232.

Figueredo-Cardenas G, Anderson KD, Chen Q, Veeman CL, Reiner A (1994) Relative survival of striatal projection neurons and interneurons after intrastriatal injection of quinolinic acid in rats. Exp Neurol 129:37-56.

Figueredo-Cardenas G, Harris C, Anderson KD, Reiner A (1998) Relative resistance of striatal neurons containing calbindin or parvalbumin to quinolinic acid-mediated excitotoxicity compared to other striatal neuron types. Exp Neurol 149:356-372.

Friedrich G, Soriano P (1991) Promoter traps in embryonic stem cells: a 
genetic screen to identify and mutate developmental genes in mice. Genes Dev 5:1513-1523.

Fusco FR, Chen Q, Lamoreaux WJ, Figueredo-Cardenas G, Jiao Y, Coffman J, Surmeier DJ, Honig MG, Carlock LR, Reiner A (1999) Cellular localization of huntingtin in striatal and cortical neurons in rats: lack of correlation with neuronal vulnerability in Huntington's disease. J Neurosci 19:1189-1202.

Goldowitz D, Moran TH, Wetts R (1992) Mouse chimeras in the study of genetic and structural determinants of behavior. In: Techniques for the generic analysis of brain and behavior (Goldowitz D, Wahlsten D, Wimer RE, eds), pp 271-290. Amsterdam: Elsevier.

Goldowitz D, Hamre KM, Przyborski SA, Ackerman SL (2000) Granule cells and cerebellar boundaries: analysis of Unc $5 \mathrm{~h} 3$ mutant chimeras. J Neurosci 20:4129-4137.

Gusella JF, MacDonald ME (1996) Trinucleotide instability: a repeating theme in human inherited disorders. Annu Rev Med 47:201-209.

Gutekunst CA, Li SH, Yi H, Mulroy JS, Kuemmerle S, Jones R, Rye D, Ferrante RJ, Hersch SM, Li XJ (1999) Nuclear and neuropil aggregates in Huntington's disease: relationship to neuropathology. J Neurosci 19:2522-2534.

Hackham AS, Wellington CL, Hayden MR (1998) The fatal attraction of polyglutamine-containing proteins. Clin Genet 53:233-242.

Harrington KM, Kowall NW (1991) Parvalbumin-immunoreactive neurons resist degeneration in Huntington's disease striatum. J Neuropathol Exp Neurol 50:309.

Hedreen JC, Peyser CE, Folstein SE, Ross CA (1991) Neuronal loss in layers V and VI of cerebral cortex in Huntington's disease. Neurosci Lett 133:257-261.

Hodgson JG, Agopyan N, Gutekunst CA, Leavitt BR, LePiane F, Singaraja R, Smith DJ, Bissada N, McCutcheon K, Nasir J, Jamot L, Li XJ, Stevens ME, Rosemond E, Roder JC, Phillips AG, Rubin EM, Hersch SM, Hayden MR (1999) A YAC mouse model for Huntington's disease with full-length mutant huntingtin, cytoplasmic toxicity, and selective striatal neurodegeneration. Neuron 23:181-192.

Huntington's Disease Collaborative Research Group (1993) A novel gene containing a trinucleotide repeat that is expanded and unstable on the HD chromosome. Cell 72:971-983.

Jiao Y, Sun Z, Lee T, Fusco FR, Kimble TD, Meade CA, Cuthbertson S, Reiner A (1999) A simple and sensitive antigen retrieval method for free-floating and slide-mounted tissue sections. J Neurosci Methods 93:149-162.

Karle E, Anderson KD, Medina L, Reiner A (1996) Light and electron microscopic immunohistochemical study of dopaminergic terminals in pigeon striatum using antisera against tyrosine hydroxylase and dopamine. J Comp Neurol 369:109-124.

Kawaguchi Y, Wilson CJ, Augood SJ, Emson PC (1995) Striatal interneurons: chemical, physiological, and morphological characterization. Trends Neurosci 18:527-535.

Kim TW, Tanzi RE (1998) Neuronal intranuclear inclusions in polyglutamine diseases: nuclear weapons or nuclear fallout. Neuron 21: 657-659.

Kiyama H, Seto-Ohshima A, Emson PC (1990) Calbindin D28k as a marker for the degeneration of striatonigral pathway in Huntington's disease. Brain Res 525:209-214.

Kuan CY, Elliott EA, Flavell RA, Rakic P (1997) Restrictive clonal allocation in the chimeric mouse brain. Proc Natl Acad Sci USA 94:3374-3379

Landwehrmeyer GB, McNeil SM, Dure IV LS, Ge P, Aizawa H, Huang Q, Ambrose CM, Duyao MP, Bird ED, Bonilla E, deYoung M, Avila-Gonzales AJ, Wexler NS, DiFiglia M, Gusella JF, MacDonald ME, Penney JB, Young AB, Vonsattel JP (1995) Huntington's disease gene: regional and cellular expression in brain of normal and affected individuals. Ann Neurol 37:218-230.

Leavitt BR, Guttman JA, Hodgson JG, Kimel G, Singaraja R, Vogl AW, Hayden MR (2000) Wild-type huntingtin reduces the cellular toxicity of mutant huntingtin in vivo. Am J Hum Genet 68:313-324.

Le Dourain N, McLaren A (1984) Chimeras in developmental biology. London: Academic.

Li SH, Li XJ (1998) Aggregation of N-terminal huntingtin is dependent on the length of its glutamine repeats. Hum Mol Genet 7:801-806.

Li SH, Schilling G, Young III WS, Li XJ, Margolis RL, Stine OC, Wagster MV, Abbott MH, Franz ML, Ranen NG, Folstein SE, Hedreen JC, Ross CA (1993) Huntington's disease gene (IT15) is widely expressed in human and rat tissues. Neuron 11:985-993.

Loren I, Emson PC, Fahrenkrug J, Bjorkklund A, Alumets, Hakanson R, Sundler F (1979) Distribution of vasoactive intestinal polypeptide (VIP) in the rat and mouse brain. Neuroscience 4:1953-1976.

Maat-Schieman ML, Dorsman JC, Smoor MA, Siesling S, Van Duinen SG, Verschuuren JJ, den Dunnen JT, Van Ommen GJ, Roos RAC (1999) Distribution of inclusions in neuronal nuclei and dystrophic neurites in Huntington's disease brain. J Neuropathol Exp Neurol 58:129-137.

Mangiarini L, Sathasivam K, Seller M, Cozens B, Harper A, Hetherington C, Lawton M, Trottier Y, Lehrbach H, Davies SW, Bates G (1996) Exon 1 of the HD gene with an expanded CAG repeat is sufficient to cause a progressive neurological phenotype in transgenic mice. Cell 87:493-506.

Martindale D, Hackham A, Wieczorek A, Ellerby L, Wellington C, McCutcheon K, Singaraja R, Kazemi-Esfarjani P, Devon R, Kim SU, Bredesen DE, Tufaro F, Hayden MR (1998) Length of huntingtin and its polyglutamine tract influences localization and frequency of intracellular aggregates. Nat Genet 18:150-154

Metzler M, Chen N, Helgason CD, Graham RK, Nichol K, McCutcheon K, Nasir J, Humphries RK, Raymond LA, Hayden MR (1999) Life without huntingtin: normal differentiation into functional neurons. J Neurochem 72:1009-1018.

Myers RH, Leavitt J, Farrer LA, Jagadeesh J, McFarlane H, Mastromauro CA, Mark RJ, Gusella JF (1989) Homozygote for Huntington's disease. Am J Hum Genet 45:615-618.

Narain Y, Wyttenbach A, Rankin J, Furlong RA, Rubinsztein DC (1999) A molecular investigation of true dominance in Huntington's disease. J Med Genet 36:739-746.

Nasir J, Floresco SB, O'Kusky JR, Borowski A, Richman JM, Zeisler J, Phillips AG, Hayden MR (1995) Targeted disruption of the Hunting ton's disease gene results in embryonic lethality and behavioral and morphological changes in heterozygotes. Cell 81:811-823.

Oberdick J, Wallace JD, Lewin A, Smeyne RJ (1994) Transgenic expression to monitor dynamic organization of neuronal development: use of the $E$. coli lac $Z$ gene product, $\beta$-galactosidase. NeuroProtocols 5:54-62.

Persichetti F, Carlee L, Faber PW, McNeil SM, Ambrose CM, Srinidhi J, Anderson MA, Barnes GT, Gusella JF, MacDonald ME (1996) Differential expression of normal and mutant Huntington's disease gene alleles. Neurobiol Dis 3:183-190.

Preisinger E, Jordan BM, Kazantsev A, Housman D (1999) Evidence for a recruitment and sequestration mechanism in Huntington's disease. Philos Trans R Soc Lond [Biol] 354:1029-1034.

Reiner A (1991) A comparison of the neurotransmitter-specific and neuropeptide-specific neuronal cell types present in turtle cortex to those present in mammalian isocortex: implications for the evolution of isocortex. Brain Behav Evol 38:53-91.

Reiner A, Anderson KD (1990) The patterns of neurotransmitter and neuropeptide co-occurrence among striatal projection neurons: conclusions based on recent findings. Brain Res Rev 15:251-265.

Reiner A, Albin RL, Anderson KD, D'Amato CJ, Penney JB, Young AB (1988) Differential loss of striatal projection neurons in Huntington's disease. Proc Natl Acad Sci USA 85:5733-5737.

Richfield EK, Maguire-Zeiss KA, Cox C, Gilmore J, Voorn P (1995) Reduced expression of preproenkephalin in striatal neurons from Huntington's disease patients. Ann Neurol 37:335-343.

Rigamonti D, Bauer JH, De-Fraja C, Conti L, Sipione S, Sciorati C, Clementi E, Hackham A, Hayden MR, Li Y, Cooper JK, Ross CA, Govoni S, Vincenz C, Cattaneo E (2000) Wild-type huntingtin protects from apoptosis upstream of caspase-3. J Neurosci 20:3705-3713.

Roos RAC (1986) Neuropathology of Huntington's chorea. Handbook Clin Neurol 5:315-326.

Sapp E, Ge P, Aizawa H, Bird E, Penney JB, Young AB, Vonsattel JP, DiFiglia M (1995) Evidence for a preferential loss of enkephalin immunoreactivity in the external globus pallidus in low grade HD using high resolution image analysis. Neuroscience 64:397-404.

Sapp E, Schwarz C, Chase K, Bhide PG, Young AB, Penney J, Vonsattel JP, Aronin N, DiFiglia M (1997) Huntingtin localization in brains of normal and Huntington's disease patients. Ann Neurol 42:604-612.

Saudou F, Finkbeiner S, Devys D, Greenberg ME (1998) Huntingtin acts in the nucleus to induce apoptosis, but death does not correlate with the formation of intranuclear inclusions. Cell 95:55-66.

Schauwecker PE, Steward O (1997) Genetic determinants of susceptibility to excitotoxic cell death: implications for gene targeting approaches Proc Natl Acad Sci USA 94:4103-4108.

Schmued LC, Albertson C, Slikker Jr W (1997) Fluoro-jade: a novel fluorochrome for the sensitive and reliable histochemical localization of neuronal degeneration. Brain Res 751:37-46.

Sharp AH, Loev SJ, Schiling G, Li SH, Li XJ, Bao J, Wagster MV Kotzuk JA, Steiner JP, Lo A, Hedreen J, Sisodia S, Snyder SH, Dawson TM, Ryugo DDK, Ross CA (1995) Widespread expression of Huntington's disease gene (IT15) protein product. Neuron 14:10651074.

Sisodia SS (1998) Nuclear inclusion in glutamine repeat disorders: are they pernicious, coincidental, or beneficial? Cell 95:1-4.

Storey E, Kowall NW, Finn SF, Mazurek MF, Beal MF (1992) The cortical lesion of Huntington's disease: further neurochemical characterization and reproduction of some of the histological and neurochemical features by N-methyl-D-aspartate. Ann Neurol 32:526-534.

Trottier Y, Devys D, Imbert G, Saudou F, An I, Lutz Y, Weber C, Agid Y, Hirsch EC, Mandel JL (1995) Cellular localization of the Huntington's disease protein and discrimination of the normal and mutated form. Nat Genet 10:104-110.

Vonsattel JP, Myers RH, Stevens TJ, Ferrante RJ, Bird ED, Richardson EP (1985) Neuropathological classification of Huntington's disease. J Neuropathol Exp Neurol 44:559-577. 
Wexler NS, Young AB, Tanzi RE, Travers H, Starosta-Rubinstein S, Penney JB, Snodgrass SR, Shoulson I, Gomez F, Ramos-Arroyo MA, Penchaszadeh GK, Moreno H, Gibbons K, Faryniarz A, Hobbs W, Anderson MA, Bonilla E, Conneally PM, Gusella JF (1987) Homozygotes for Huntington's disease. Nature 326:194-197.

Wheeler VC, White JK, Gutekunst CA, Vrbanac V, Weaver M, Li XJ, Li SH, Yi H, Vonsattel JP, Gusella JF, Hersch S, Auerbach W, Joyner AL, MacDonald ME (1999) Long glutamine tracts cause nuclear localization of a novel form of huntingtin in medium spiny striatal neurons in $H d h^{Q 92}$ and $H d h^{Q 111}$ knock-in mice. Hum Mol Genet 9:503-513.

White JK, Auerbach W, Duyao MP, Vonsattel JP, Gusella JF, Joyner AL, MacDonald ME (1997) Huntingtin is required for neurogenesis and is not impaired by the Huntington's disease CAG expansion. Nat Genet 17:404-410.

Wilson RS, Como PG, Garron DC, Klawans HL, Barr A, Klawans D (1987) Memory failure in Huntington's disease. J Clin Exp Neuropsychol 9:147-154.

Wood JD, McLaughlin JC, Harper PS, Lowenstein PR, Jones AL (1996) Partial characterization of murine huntingtin and apparent variations in the subcellular localization of huntingtin in human, mouse, and rat brain. Hum Mol Genet 5:481-487.

Zeitlin S, Liu JP, Chapman DL, Papaiopnnou VE, Efstratiadis A (1995) Increased apoptosis and early embryonic lethality in mice nullizygous for the Huntington's disease gene homologue. Nat Genet 11:155-163. 